contemporary dames - fallible, inconsistent, compelling, frustrating, paradoxical, both emotionally strong and fragile - have much to tell us about our complex age of troubled emancipation. By delving far deeper into the postfeminist theories, exploring the contesting voices as well as the complexities and lived messiness of our everyday, I felt that the author might have reached different conclusions. And this is to say nothing of the complex issues of race, racial identities and ethnicity that needed fleshing out in more detail.

For all my reservations this highly readable and intellectually accessible book got me thinking anew, igniting my passion for feminism, and reminding me that good critical analysis should inspire activism.

\title{
references
}

Janet McCabe

Dow, B. (1994) Prime-Time Feminism: Television, Media Culture, and the Women's Movement Since 1970, Philadelphia: University of Pennsylvania Press.

Haskell, M. (1974) From Reverence to Rape, New York: Holt, Rinehart and Winston.

Kaplan, E.A. (1978) editor, Women in Film Noir, London: British Film Institute, new edition, reprinted in 2000 .

doi: $10.1057 /$ fr. 2009.48

\section{pin-up grrrls: feminism, sexuality, popular culture}

Maria Elena Buszek, Duke University Press, Durham and London, 2006,

ISBN 978-0-8223-3746-1, £65.00 (hardback); £1l.99 (paperback)

In Pin-Up Grrrls, feminist art scholar Buszek optimistically traces the development of feminism and the assertion of female sexuality in the public sphere through a well-illustrated focus on a 150-year history of the female pinup. This visual genre encompasses ambiguously suggestive full-body photographs of singular women. Through meticulous research, presented in a chronological narrative structure, Buszbek demonstrates the complex interaction between the pin-up and the historical contexts in which it articulates female sexuality.

The book's rationale can be understood within the context of an American 'thirdwave' feminist art practice that celebrates a sense of sexual freedom through subversive appropriation of the pin-up. Examples are Cindy Sherman, who explored the genre from the 1970s onwards; Suzie Bright in the 1980s; and Annie Sprinkle in the 1990s. Their practices are characterized by an appropriation of the female as spectacle, sometimes flatly, without irony, but always with an 
awareness of the ambivalent performativity of womanhood. The embrace of the pin-up as a rebellious and celebratory strategy in the 1990s and early twentyfirst century by a range of 'Bad Girls' seemed based on a wish to break away from a feminist continuity. Yet, Buszbek shows that 'feminist uses of the genre long predate the popular women's liberation movement' (p. 4).

The pin-up emerged with the inception of photographic reproduction in the $1850 \mathrm{~s}$, when theatre performers started to present themselves through mass-produced photographic 'cartes de visite'. These became part of, for example, calling card collections of bourgeois households, effectively early examples of social networking media. As such, the image of the burlesque actress, a still performance of independent flirtatious femininity, entered the world of the white middle-class educated woman. Simultaneously, the first wave of feminism developed, driven by a middle-class women's liberation movement.

In 1894, the 'New Woman' was coined by Sarah Grand, as a model of the modern female active in the urban public realm, 'from suffragists to anarchists to flappers' (p. 78). Although varied in terms of class and sexuality, Buszbek shows she was 'Anglo', rather than 'Oriental', Latin- or African-American. Cartoons of the New Woman showed white middle-class women in a variety of powerful poses, often desired and, in the case of the 'Gibson Girls', also as desiring. These handdrawn illustrations became a prototype for the modern pin-up: feminine, often romantic, yet strong and independent. Interestingly, in that era, photographer Frances Benjamin Johnston produced an early series of gender-bending selfportraits. By the start of the twentieth century, the New Woman became fashionable in American theatre and Hollywood cinema - to underpin the consumption of these images by an eager female audience, the fanzine, such as Photoplay, appeared.

Although the 1930s presented a challenge to the suffrage movement, illustrated by the demise of feminist representation in cinema, the start of WWII saw the return of the subversive pin-up, notably the 'Vagra Girl', at once beautiful, patriotic, independent and sexual. In the postwar years, a renewed anti-feminism appeared, as shown, for example, in Playboy magazine, as a 'wholesome' alternative to the 'femme fatale'.

Yet, during the 1950s, pin-up fantasies of dominatrix women also gradually infiltrated American popular culture, in which model Betty Page stood out for her humorous exposure of the theatrical construction of such images and who was to become an inspiration for third-wave art appropriation of the pin-up. In addition, the image of the professional black woman entered the popular postwar realm though magazine Ebony, an African-American version of Life magazine established in 1945, which presented pin-ups of role models for a variety of professional women, from music performers to college graduates. 
The pin-up, then, showed a range of attitudes towards women in postwar America, and as such entered the art world as a visual icon of Pop Art. This appropriation of the pin-up was not necessarily feminist, nor critical of commercial contexts. Yet such critique became a possibility during the following decade, through the development of countercultural civil rights activism, as well as critical art installation and performance practices. At the same time, a second wave of feminism developed that put the fight for sexual freedom high on the agenda.

A feminist third wave emerged during the 1980s, initially as a response by women of colour to a white dominance within the feminist movement. As a pluralist form of feminism, the third wave seems at once ubiquitous and invisible, including multiple political agendas. Resultant artwork utilizes contradictory images of femininity, recognizing multiple sexual, ethnic, racial and class identity subjectivities. Arguably, postmodernist feminist artists took the historical gains in sexual freedom for granted and ran away with it, producing their own images of female sexuality, at times queer, burlesque and critical. Buszbek's historical analysis shows that in its ambivalent representation of female sexuality, the pinup offers a useful vehicle for feminist artists to explore such complex issues.

\section{Hillegonda C. Rietveld}

doi: $10.1057 /$ fr. 2009.49

\section{hollywood heroines: women in film Noir and the female Gothic film}

Helen Hanson, I.B. Tauris, London and New York, 2007, 256pp., ISBN 978-1-84511-561-6, $£ 15.99$ (paperback); ISBN 978-1-84511-562-3, £40.00 (hardback)

Helen Hanson's book casts a close eye on representations of women in the Hollywood genres of film noir and the gothic film, with an approach which takes in issues of genre, context and 1970s feminist film theory. Hanson sets out to confront what she views as two major faults in film noir criticism, challenging the delineation of noir women into the two oppositional categories of femme fatale and virginal redeemer, and aiming to correct the marginalisation of the female gothic film as a result of an overriding academic focus on film noir. The author's attempt to move readings of the female beyond the obviously stark and restrictive limitations of early feminist criticism has a ready appeal, and she forms a convincing argument for the consideration of the 'working-girl investigator' figure evident in films such as I Wake Up Screaming (1941), Phantom Lady (1944) and The Dark Corner (1946). Hanson draws an important 